\title{
Comparative studies on blood electrolytes of the fresh water fish, Notopterus notopterus from three aquatic bodies
}

\author{
R. S. Kulkarni \\ Department of Zoology \\ Gulbarga University Kalaburgi - 585106 \\ Karnataka, India \\ E-mail address: rskgug@gmail.com
}

Keywords: Blood electrolytes; Notopterus notopterus

\begin{abstract}
The present study is undertaken to determine baseline levels of blood electrolytes for the fish, N.notopterus collected from three different aquatic bodies situated at different locations around Gulbarga region. The electrolytes such as sodium and potassium levels are having some difference in the fish collected from the three aquatic bodies. The data for blood Sodium $88.49 \pm$ $16.68 \mathrm{mmol} / \mathrm{l}$. in the fish from Bheema River, $101.32 \pm 4.17 \mathrm{mmol} / \mathrm{l}$. in the fish from Kagina River, and $87.5 \pm 3.41, \mathrm{mmol} / \mathrm{l}$. in the fish from Saradgi Stream., Potassium $14.48 \pm 1.14 \mathrm{mmol} / \mathrm{l}$. in the fish from Bheema River, $14.63 \pm 1.15 \mathrm{mmol} / \mathrm{l}$. in the fish from Kagina River, $13.19 \pm 0.70 \mathrm{mmol} / \mathrm{l}$. in the fish from Saradgi Stream. The blood calcium data are $9.00 \pm 0.30 \mathrm{mg} / \mathrm{dl}$. in the fish from Bheema River, $8.69 \pm 0.50 \mathrm{mg} / \mathrm{dl}$. in the fish from Kagina River, and $8.39 \pm 0.45 \mathrm{mg} / \mathrm{dl}$. in the fish from Saradgi Stream. Based on the results obtained for blood electrolytes, the fish N.notopterus from three aquatic bodies are although healthy and thriving well, the Bheema River provides better environmental conditions.
\end{abstract}

\section{INTRODUCTION}

The physical and chemical changes in aqueous environment often cause some physiological changes in fish, thus, the water quality of an aquatic body is very crucial because it determines the productivity and other parameters necessary for fish survival. Environmental factors such as $\mathrm{pH}$, turbidity, alkalinity, dissolved oxygen, temperature and conductivity influence the rate of reaction of pollutants entering the water or the lethal effects on the aquatic organisms (Fagbenro, 2002). Water temperature affects all aspects of metabolism and at high temperatures metabolic rate increases alkalinity, acidity and $\mathrm{pH}$ determine fish health and the well-being of fish (Ross and Ross, 2002)

The blood electrolytes which are sodium $\left(\mathrm{Na}^{+}\right)$, potassium $\left(\mathrm{K}^{+}\right)$, calcium $\left(\mathrm{Ca}^{++}\right)$, and phosphorus $\left(\mathrm{P}^{+}\right)$are commonly used to determine the physiological characteristics, toxicity and health status of fish (Percin et al.,2010). Monovalent ions namely, sodium $\left(\mathrm{Na}^{+}\right)$, and potassium $\left(\mathrm{K}^{+}\right)$play an important role in osmoregulation and homeostasis. In vertebrates, the $\mathrm{Na}^{+}$ concentration in the extracellular fluid surpasses that in the cytosol whereas $\mathrm{K}^{+}$is higher in the intracellular fluid compared to the plasma. Thus, the levels of serum electrolytes offer important knowledge concerning the health status of diseases of and impact of stress on fish (Wurst and Stickney, 1989., Evans, 1993)

The present study is undertaken to determine baseline levels of blood electrolytes for the fish, N.notopterus collected from three different aquatic bodies situated at different locations around Gulbarga region. 


\section{MATERIALS AND METHODS}

Live specimens of the Indian fresh water fish, N.notopterus (about 30 fishes) were obtained from the aquatic bodies situated at, Bheema River, Kagina River and Saradgi stream situated near Gulbarga, Karnataka State, India and transported in aerated containers to the laboratory. They were given a minimum period of a weeks to acclimatize to laboratory conditions during which time they were fed with earth worms, boiled eggs and guppy fishes obtained locally to avoid the possible effect of starvation. All sexes were used without discrimination.

The fish blood samples obtained from the caudal circulation with the aid of a heparinized $2 \mathrm{~cm}$ disposable plastic syringe and a 21 gauge disposable hypodermic needle. Serum was obtained from blood samples by centrifugation and then drawn and used for the determination of sodium, potassium, calcium and phosphorous. Sodium and Potassium were determined by colorimetric method. Calcium is determined by Modified Arsenazo method. Phosphorus is determined by Molybdate UV method.

\section{STATISTICAL TREATMENT OF THE DATA:}

The difference in the electrolyte parameters was studied by adopting varied statistical methods. The student' $t$ ' test was carried out to know the levels of significance using the standard formula. One way ANOVA of the tests were carried out by using statistical software SPSS 7.5

\section{RESULTS AND DISCUSSION}

The electrolytes such as sodium and potassium levels are having some difference in the fish collected from the three aquatic bodies. The data recorded for blood Sodium is $88.49 \pm 16.68$ $\mathrm{mmol} / \mathrm{l}$. in the fish from Bheema River, $101.32 \pm 4.17 \mathrm{mmol} / \mathrm{l}$. in the fish from Kagina River, and $87.5 \pm 3.41, \mathrm{mmol} / \mathrm{l}$. in the fish from Saradgi Stream., blood Potassium- $14.48 \pm 1.14 \mathrm{mmol} / \mathrm{l}$. in the fish from Bheema River, $14.63 \pm 1.15 \mathrm{mmol} / \mathrm{l}$. in the fish from Kagina River, $13.19 \pm 0.70 \mathrm{mmol} / \mathrm{l}$. in the fish from Saradgi Stream. The blood calcium level data recorded are $9.00 \pm 0.30 \mathrm{mg} / \mathrm{dl}$. in the fish from Bheema River, $8.69 \pm 0.50 \mathrm{mg} / \mathrm{dl}$. in the fish from Kagina River, and $8.39 \pm 0.45 \mathrm{mg} / \mathrm{dl}$. in the fish from Saradgi Stream. Based on the results obtained for blood electrolytes, the fish N.notopterus collected from three aquatic bodies are although healthy and thriving well, the Bheema River provides better environmental conditions. The results are presented in the Table -01 . In the present study sodium levels are significantly higher in the fish collected from Kagina River, potassium and calcium levels found slightly lower however, the means are not significantly different. Thus, many parameters have been used as quantitative indicators of external environment. The physicochemical parameters of the water play an impotent role in the fish physiology.

The studies of blood electrolyte parameters are good indicators of identifying the health of fish. The electrolytes are most important substances which influence the distribution and retention of body water. Sodium (chief cation of extracellular fluid) and potassium (chief cat ion of intracellular fluid) are the most important osmotically effective electrolytes. The blood sodium and potassium levels are mostly found to be having some difference in the fish collected from the three aquatic bodies. Calcium is present in the body in larger amounts than in any other mineral element. It is present in the bones as deposits of calcium phosphate in a soft fibrous matrix. It is also present in the small concentrations in body fluids. The ionized calcium in the body plays an impotent role in blood coagulation and maintaining the normal excitability of muscles. The blood calcium levels are almost similar in the fish N.notopterus collected from different aquatic bodies. The data recorded are $9.00 \pm 0.30 \mathrm{mg} / \mathrm{dl}$ (Bheema), $8.69 \pm 0.50 \mathrm{mg} / \mathrm{dl}$ (Kagina), and $8.39 \pm 0.45 \mathrm{mg} / \mathrm{dl}$ (Saradgi).

Any environmental disturbance can be considered a potential source of stress as it prompts a number of responses in the animal to deal with the physiological changes triggered by exterior changes, these responses can be detected in fish and in other vertebrates in the form of changes in the hematological and biochemical or alteration in the enzyme activity (Donaldson, 1981). Since 
measurement of hematological parameters reflect the poor or good condition of fish, more quietly then other commonly measured parameters and they respond quickly to changes in the environmental condition (Atkinson and Judd, 1978).

Electrolyte $\left(\mathrm{Na}^{+}, \mathrm{K}^{+}, \mathrm{P}^{+}\right.$, and $\mathrm{Ca}^{++}$levels indicate the operation of a variety of homeostatic mechanisms in the body (Clarke, 1998). Sodium $\left(\mathrm{Na}^{+}\right)$, potassium $\left(\mathrm{K}^{+}\right)$and Chloride $\left(\mathrm{Cl}^{-}\right)$play an important role in osmoregulation and homeostasis. In vertebrates, the $\mathrm{Na}^{+}$concentration in the extracellular fluid surpasses that in the cytosol, whereas $\mathrm{K}^{+}$is higher in the intracellular fluid compared to the plasma. In fish, $\mathrm{Na}^{+}$enters the gill cells from the blood; co-transported with $\mathrm{K}^{+}$and $\mathrm{Cl}^{-}$and driven by an electrochemical gradient favorable to $\mathrm{Na}^{+} \cdot \mathrm{Cl}$ exits the apical portion of the cell through a channel that is very similar to the defective structure that produces cystic fibrosis in animals. $\mathrm{Na}^{+}$is transported back across the basolateral membrane into the blood by $\mathrm{Na}^{+} / \mathrm{K}^{+}$ activated ATPase. Furthermore, the $\mathrm{Na}^{+} / \mathrm{K}^{+}$ratio is vital for the ion permeability barriers in the cell membrane. ( Evans, 1993). One of the divalent ions, calcium $\left(\mathrm{Ca}^{++}\right)$, serves a number of functions in fish. It combines with phosphorus $\left(\mathrm{P}^{+}\right)$for the deposition of bone. It is possible that bone serves as a reservoir of calcium for plasma and tissues. Additionally, $\mathrm{Ca}^{++}$appears to be important in the reproduction and mitochondrial functions. It is generally recognized that $\mathrm{Ca}^{++}$has an important role in osmoregulation (Wurst and Stickney, 1989).

In fish, the sodium and potassium are predominant electrolytes, with the predominance of sodium in the serum and in other fluids and potassium in extracellular fluids. The function of electrolytes, mainly the sodium and potassium, is to regulate the acid-basic balance maintaining thereby an ionic adequacy on the tissue functions (Davis, 2004; Tavares-Dias et al., 2008). Calcium taken up from the water in freshwater fish follows a transcellular, hormone-controlled pathway located in the chloride cells of the gills. In the present study sodium levels are significantly higher in the fish collected from Kagina River, potassium and calcium levels found slightly lower however, the means are not significantly different. Thus, many parameters have been used as quantitative indicators of external environment.

In conclusion, based on the results obtained for blood electrolytes show that the fish N.notopterus from the three aquatic bodies are healthy and thrive well. The aquatic body Bheema River provides better environmental conditions

Table 1: Blood electrolytes parameter of fish Notopterus notopterus collected from different aquatic water bodies of Gulbarga

\begin{tabular}{|l|l|l|l|l|}
\hline $\begin{array}{l}\text { Parameters/Water } \\
\text { bodies }\end{array}$ & Sodium & Potassium & Calcium & Phosphorus \\
\hline Bheema River & $88.49 \pm 16.68$ & $14.98 \pm 1.14$ & $9.00 \pm 0.30$ & $0.097 \pm 0.001$ \\
\hline Kagina River & $101.32 \pm 4.17$ & $14.63 \pm 1.15$ & $8.69 \pm 0.50$ & $0.093 \pm 0.001$ \\
\hline Saradagi Stream & $57.5 \pm 3.41$ & $13.19 \pm 0.70$ & $8.39 \pm 0.45$ & $0.093 \pm 0.002$ \\
\hline
\end{tabular}




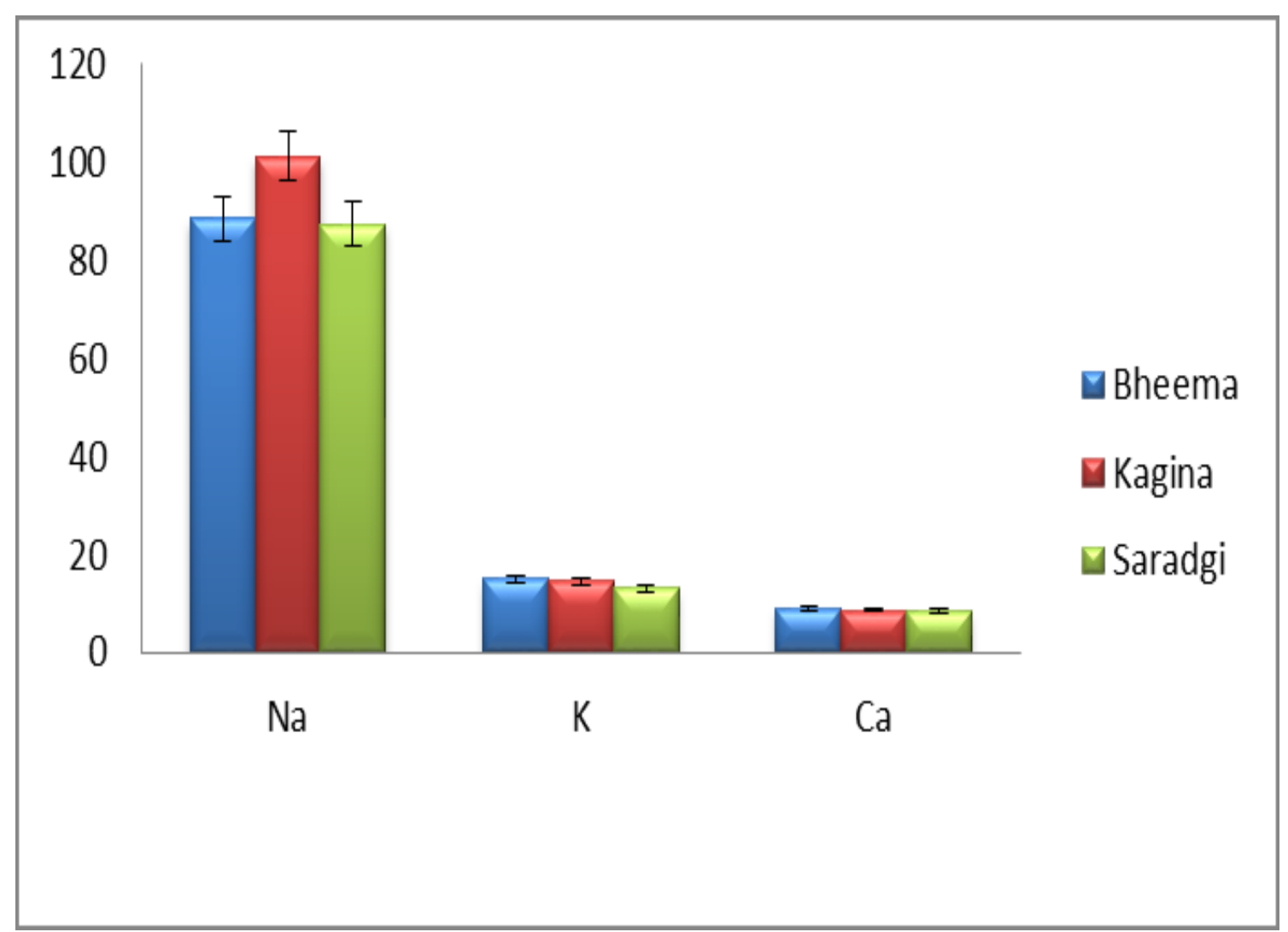

Fig 1: Showing blood electrolytes of the fish, N. notopterus from aquatic bodies of Gulbarga.

Values are expressed as Mean $\pm \mathrm{SD}, \mathrm{N}=06$. Blood sodium and potassium in $\mathrm{mmol} / \mathrm{l}$, calcium in $\mathrm{mg} / \mathrm{dl}$

\section{Acknowledgement}

The author R.S. Kulkarni is grateful to University Grants Commission, New Delhi for selecting Emeritus fellowship (2014-15 batch/starting from feb.2015) .

\section{References}

[1] Atkinson, J. and F.W. Judd, F.W. (1978). Comparative haematology of Lepomis microlophus and Cichlosoma cyanogutatum. Copeia, 12: 230-237.

[2] Butkus A, Roche PJ, Fernley RT, Haralambidis J, Penschow JD, Ryan GB, Trahair JF, Tregear GW, Coghlan JP 1987 Purification and cloning of a corpuscles of Stannius protein from Anguilla australis. Mol Cell Endocrinol 54:123-133 2.

[3] Butkus A, Roche PJ, Fernley RT, Haralambidis J, Penschow JD, Ryan GB, Trahair JF, Tregear GW, Coghlan JP 1987 Purification and cloning of a corpuscles of Stannius protein from Anguilla australis. Mol Cell Endocrinol 54:123-133

[4] Clarke, F. (1998). A review of the scientific justifications for maintaining the cetaceans in captivity. A report for the Whale and Dolphin Conservation Society (WDCS).

[5] Davis, K. (2004). Temperature affects physiological stress response to acute confinement in sunshine bass (Morone chrysops $\mathrm{x}$ Morone saxatilis). Comparative Biochemistry and Physiology, 139A: 433-440.

[6] Donaldson, E.M. (1981). The Pituitary Interregnal Axis as an Indicator of Stress in Fish In: Pickering, A.D. (Ed.) Stress in fish. Academic Press, London, pp: 11-47. 
[7] Evans, D.H. (1993)The Physiology of Fishes. $2^{\text {nd }}$ Edn.,CRC press, Boca Raton, pp: 49-73.

[8] Fagbenro, O. A. (2002). Tilapia: fish for thought. 32nd Inaugural Lecture, Federal University of Technology, Akure, Nigeria. 77pp.

[9] Fenwick JC, Brasseur JG 1991 Effects of stanniectomy and experimental hypercalcemia on plasma calcium levels and calcium influx in American eels, Anguilla rostrata, LeSueur. Gen Comp Endocrinol 82:459-465

[10] Lu M, Wagner GF, Renfro JL 1994 Stanniocalcin stimulates phosphate reabsorption by flounder renal proximal tubule in primary culture. Am J Physiol 267:R1356-R1362

[11] Lu M, Wagner GF, Renfro JL 1994 Stanniocalcin stimulates phosphate reabsorption by flounder renal proximal tubule in primary culture. Am J Physiol 267:R1356-R1362

[12] Madsen KL, Tavernini MM, Yachimec C, Mendrick DL, Alfonso PJ, Buergin M, Olsen HS, Antonaccio MJ, Thomson AB, Fedorak RN 1998 Stanniocalcin: a novel protein regulating calcium and phosphate transport across mammalian intestine. Am J Physiol 274:G96-G102

[13] Milet C, Buscaglia M, Chartier MM, Martelly E, Lopez E 1984 Comparative effects of an extract of Anguilla Stannius corpuscles and of an active fragment of human parathyroid hormone (1-34 hPTH) on an anuran batracian, Xenopus laevis. C R Seances Acad Sci III 297:33-36

[14] Percin, F., Sibel, K., Kursat, F and Sahin, S. (2010). Serum electrolytes of wild and captive Bluefin Tuna (Thunnus thynnus L.) in Turkish Seas J. Anim. Vet. Adv. 9(16): 22072213.

[15] Ross, B. and Ross, L.G. (2002). Anaesthetic and Seductive for Aquatic Animals. $2^{\text {nd }}$ Edition, Blackwell Science Ltd.

[16] So YP, Fenwick JC 1977 Relationship between net 45calcium influx across a perfused isolated eel gill and the development of post-stanniectomy hypercalcemia. J Exp Zool 200:259-264

[17] Srivastav AK, KS 1982 Calcemic responses of Stannius corpuscles extract in parrots, Psittacula psittacula. Experientia 38:869-870

[18] Tavares-Dias, M., Moraes, F.R., Imoto, M.E. (2008). Hematological parameters in two neotropical freshwater teleost, Leporinus macrocephalus (Anostomidae) and Prochilodus lineatus (Prochilodontidae). Bioscience Journal, 24: 96-101

[19] Wagner GF 1994 The molecular biology of the corpuscles of stannius and regulation of stanniocalcin gene expression. In: Hochachka PW, Mommsen TP (eds) Fish Physiology. Academic Press, Amsterdam, pp 273-306

[20] Wagner GF, Hampong M, Park CM, Copp DH 1986 Purification, characterization, and bioassay of teleocalcin, a glycoprotein from salmon corpuscles of Stannius. Gen Comp Endocrinol 63:481-491

[21] Wagner GF, Jaworski E 1994 Calcium regulates stanniocalcin mRNA levels in primary cultured rainbow trout corpuscles of Stannius. Mol Cell Endocrinol 99:315-322 